\title{
THE MERE EVIDENCE RULE: LIMITATIONS ON SEIZURE UNDER THE FOURTH AMENDMENT
}

In 1961, the United States Supreme Court, with its decision in $M a p p$ v. Ohio, ${ }^{1}$ began what has come to be an extensive re-examination of the impact of the Bill of Rights on the states' administration of criminal justice. ${ }^{2}$ Despite the large number of cases dealing with the fourth amendment since $1961,{ }^{3}$ there remains at least one area in which the state and federal views of the requirements of the fourth amendment appear to be in conflict. This conflict is illustrated by the recent California case of People v. Thayer. ${ }^{4}$ In an opinion written by Chief Justice Traynor, the Cahifornia Supreme Court rejected the venerable, although not venerated, "mere evidence rule."

The mere evidence rule purports to impose an absolute limit on the kinds of property which the governnent niay seize for use as evidence in a penal proceeding. It prohibits the seizure of mere evidence no nuatter how reasonable the search preceding that seizure. Mere evidence is anything "which is neither contraband nor tools [or more commonly, instrunientahities] nor fruits of crime, but which consists of private documents or other chattels of the defendant wanted by the government solely for its evidentiary value...."

The decision in Thayer is important for two reasons. First, it adds the weight of a respected court to the growing trend of authority ${ }^{6}$ reject-

1367 U.S. 643 (1961).

2 E.g., search and seizure: Stanford v. Texas, 379 U.S. 476 (1965); Beck v. Ohio, 379 U.S. 89 (1964); Stoner v. California, 376 U.S. 483 (1964); Ker v. California, 374 U.S. 23 (1963); search warrant: United States v. Ventresca, 380 U.S. 102 (1965); Aguilar v. Texas, 378 U.S. 108 (1964); coerced confessions: Davis v. North Carolina, 384 U.S. 737 (1966); Rogers v. Richmond, 365 U.S. 534 (1961); privilege against self-incrimination: Schmerber v. California, 384 U.S. 757 (1966); Griffin v. California, 380 U.S. 609 (1965); Murplyy v. Waterfront Comm'n, 378 U.S. 52 (1964); Malloy v. Hogan, 378 U.S. 1 (1964); counsel: Douglas v. California, 372 U.S. 353 (1963); Gideon v. Wainwright, 372 U.S. 335 (1963); police interrogation: Miranda v. Arizona, 384 U.S. 436 (1966); Escobedo v. Mlinois, 378 U.S. 478 (1964); publicity and fair trial: Sheppard v. Maxwell, 384 U.S. 333 (1966); Estes v. Texas, 381 U.S. 532 (1965). See generally Friendly, The Bill of Rights as a Code of Criminal Procedure, 53 CALIF. L. REv. 929 (1965).

3 E.g., United States v. Ventresca, supra note 2; Stanford v. Texas, supra note 2; Beck v. Ohio, supra note 2; Aguilar v. Texas, supra note 2; Stoner v. California, supra note 2; Ker v. California, supra note 2.

463 Cal. 2d 635, 408 P.2d 108, 47 Cal. Rptr. 780 (1965), cert. denied, 384 U.S. 908 (1966).

58 WrGMore, EVIDENCE $\S 2184 a$, at 45 (McNaughton ed. 1961) [hereinafter cited as WIGMORE].

${ }^{B} \mathrm{~A}$ number of states have rejected the mere evidence rule by statute, judicial decision, or both.

Oregon had a statute very similar in wording and identical in scope to the federal rule, Fed. R. CRIM. P. 41(b). State v. Chinn, 231 Ore. 259, 276, 373 P.2d 392, 400 (1962). Al- 
ing a rule which has been "condemned as unsound by virtually all modern writers." Since this is an area of the law which raises the dilemma presented by the competing values of personal hberty and effective law enforcement, ${ }^{8}$ any step toward greater doctrinal clarity is very desirable. ${ }^{9}$ Second, the rejection of the mere evidence rule by another important state court raises, in a context particularly propitious for careful analysis, the question of the degree to which the states may formulate their own procedures to implement those provisions of the Bill of Rights held to be binding on them. ${ }^{10}$

Some commentators, including Chief Justice Traynor, ${ }^{11}$ have expressed concern that the United States Supreme Court has not taken sufficient cognizance of the distinct law enforcement problems of the states in applying Bill of Rights standards developed prior to $M a p p \cdot{ }^{12}$ It has become necessary since Mapp to distinguish between those standards

though the court held in Chinn that the seizure of some beer bottles, soiled sheets, and a camera was proper because these items were instrumentalities of the crime of statutory rape, the Oregon District Attorney's Association secured an amendment to the statute to permit a warrant to issue for evidentiary material, ORE. REv. STaT. \& 141.010 (1963). Note, 43 ORE. L. REv. 333 (1964).

New Jersey bas a rule of court permitting the seizure of merely evidentiary material in felony cases. N.J. Roues $3: 2 \mathrm{~A}-2$ (c). The validity of this rule was questioned in 1964 . State v. Naturile, 83 N.J. Super. 563, 200 A.2d 617 (App. Div. 1964). The rule was subsequently' held valid in a forceful opinion by Chief Justice Weintraub. State v. Bisaccia, 45 N.J. 504, 213 A.2d 185 (1965). The Supreme Court of Iowa has indicated that it will not apply the mere evidence rule. State v. Raymond, 142 N.W.2d 444, 450-51 (1966) (dicta), quoting in part State v. Bisaccia, suprc.

New York added a provision similar to those discussed above to its searcb warrant law in 1962. N.Y. CODE CrmM. Proc. \$ 792(4). The amendment was construed and held valid in People v. Carroll, 38 Misc. 2d 630, 238 N.Y.S.2d 640 (Sup. Ct. 1963).

A more complete list of the states rejecting the mere evidence rule appears in Note, 54 GEO. L.J. 593, 594 n.8 (1966).

However, in a minority of jurisdictions the mere evidence rule bas not been rejected but rather has experienced a new vitality. E.g., Williams v. United States, 263 F.2d 487 (D.C. Cir. 1959) (dictum), cert. denied, 365 U.S. 836 (1961); Morrison v. United States, 262 F.2d 449 (D.C. Cir. 1958); see Shellow, The Continuing Vitality of the Gouled Rule: The Search for and Seizure of Evidence, 48 MARQ. L. REv. 172, 179-80 (1964). Maine has repealed a statute permitting the seizure of mere evidence and Hawaii has interpreted its statute so as not to apply to mere evidence. Note, 54 Gro. L.J. supra.

7 People v. Thayer, 63 Cal. 2d 635, 637, 408 P.2d 108, 109, 47 Cal. Rptr. 780, 781 (1965), cert. denied, 384 U.S. 908 (1966), and articles cited tberein. State v. Bisaccia, supra note 6 , at 517-18, 213 A.2d at 192-93. Among the writers not taking the view that the rule is unsound are the following: Manwaring, California and the Fourth Amendment, 16 STAN. L. Rev. 318, 327-28 (1964); Shellow, supra note 6: Note, 54 Geo. L.J., supra note 6; Comment, 54 Nw. U.L. Rev. 611 (1964); Note, 2 SAN DIEco L. Rev. 101 (1965).

8 See Traynor, Mapp v. Ohio at Large in the Fifty States, 1962 Duke L.J. 319, 326; see also Minersville School Dist. v. Gobitis, 310 U.S. 536, 596 (1940).

${ }^{9}$ Wechsler, The Challenge of a Model Penal Code, 65 HARv. L. REv. 1097, 1098 (1952). 10 Traynor, supra note 8 , at $326-31$.

11 Id. at $326-27$.

12 Friendly, supra note 2. 
which are required by the various provisions of the Bill of Rights found applicable to the states, and those standards which liave been developed pursuant to the Supreme Court's power to declare rules for the administration of justice in the federal court system. ${ }^{13}$ The former standards are applicable to the states by virtue of the supremacy clause, while the latter are not. ${ }^{14}$ These latter rules, reflecting the peculiar requirements of the federal system rather than fundamental value choices of constitutional dimension, are not necessarily appropriate means for protecting constitutional rights in the differing situations found in the states. ${ }^{15}$ The lack of substantive support for the mere evidence rule in conjunction with the language in the leading federal case to the effect that it is required by the Constitution, ${ }^{16}$ will necessitate further consideration of this distinction between constitutional and supervisory rules. ${ }^{17}$

This Comment will be devoted to an analysis of two related problems. The first is the performance of the mere evidence rule in protecting the rights of privacy and freedom from compulsory self-incrimination. The second is whether, given the unsatisfactory performance of the mere evidence rule, it is necessary to place any other restriction on the government's power of seizure in order to protect these rights.

I

\section{People v. Thayer: CALIFORNIA REJECTS THE MERE EVIDENCE RULE}

In People v. Thayer the defendants were convicted of submitting and conspiring to submit fraudulent medical care statements to the Los Angeles Bureau of Public Assistance. The prosecution contended that Dr. Thayer and his co-defendant had submitted statements to the Bureau which included charges for services not actually rendered and for services billed to others. ${ }^{18}$

13 The former are termed "constitutional" and the latter "supervisory." See Ker v. California, 374 U.S. 23, 33 (1963).

$14 \mathrm{Ker}$ v. California, supra note 13, at 31-34; Friendly, supra note 2, at 930, 938.

15 For a fuller discussion of this point, see generally Friendly, supra note 2 .

16 Gouled v. United States, 255 U.S. 298, 303-06 (1921).

17 The contention advanced in the text is that the mere evidence rule raises substantially the same issues of federalisin as Griffin v. California, 380 U.S. 609 (1965), but has even less to recommend it than the rule disallowing comment on the defendant's failure to testify which was found applicable to the states in Griffin. It is submitted that the inere evidence rule is likely to call forth the statesmanship that Judge Friendly found lacking in Griffin: "Although it is now settled that the fourteenth amendment 'incorporates' the protection of the fifth against self-incrimination, the part of statesmanship would have been to recognize that the amendment is not 'specific' with respect to comment on a defendant's failure to testify; that the 'federal rule' prohibiting this as to defendants rested on statute; and that on such a 'penumbral' issue there was room for reasonable experiment 'in the insulated chambers afforded by the several states." Friendly, supra note 2, at 940, quoting in part from Truax v. Corrigan, 257 U.S. 312, 344 (1921) (Holmes, J. dissenting).

1863 Cal. 2d at 636, 408 P.2d at 108-09, 47 Cal. Rptr. at 780-81. 
The principal evidence against the defendants was certain records belonging to Dr. Thayer ${ }^{19}$ seized by the district attorney under a search warrant issued pursuant to section 1524(4) of the California Penal Code. ${ }^{20}$ This section provides that a search warrant may issue:

When the property or things to be seized consist of any item or constitutes any evidence which tends to show a felony has been committed, or tends to show that a particular person has committed a felony. ${ }^{21}$

The sole issue on appeal was whether the state could constitutionally seize these records over the defendants' objection that the records constituted mere evidence. ${ }^{22}$ In support of their contention, the defendants argued that, smce they could not be compelled to produce the records under a subpoena because that would violate the fifth amendment privilege against self-incrimination, ${ }^{23}$ it would be anomalous to permit the records to be reached by the equally compulsory process of search and seizure. ${ }^{24}$ The district court of appeal held that the mere evidence rule was a federal constitutional requirement, that the records at issue were mere evidence, and that they were immune from seizure and hence inadmissible. ${ }^{25}$

In vacating the decision of the district court of appeal and affirming the conviction, Chief Justice Traynor made two different arguments. First, he argued that the mere evidence rule is not a federal constitutional requirement which the states are obliged to follow, but is a rule made pursuant to the federal government's supervisory power over federal law enforcement. ${ }^{26} \mathrm{He}$ also argued that, even if the mere evidence rule were a constitutional requirement, the records at issue would be instrumentalities of the crime charged and hence not immune from seizure. ${ }^{27}$ However, it

19 Petition for Hearing for the People, People v. Thayer, 63 Cal. 2d 635, 408 P.2d 108, 47 Cal. Rptr. 780 (1965), p. 16.

2063 Cal. 2 d at $636-37,408$ P.2d at 109, 47 Cal. Rptr. at 781.

21 This section was added by a 1957 amendment, Cal. Stat. 1957, ch. 1884, $\S 1$, drafted and supported by the District Attorneys' Association. Senate Comantree on tHe JUDiciary, Reg. Sess., 1957, Report pp. 389-92, in Appendex to the Journal of the Senate, Reg. SESS., 1957, vol. 1.

2263 Cal. 2 d at 637,408 P.2d at 109, 47 Cal. Rptr. at. 781.

23 The general rule is that an order to produce an incriminating document violates the privilege. Schmerber v. California, 384 U.S. 757, 763-64 (1966); 8 WIGMORE \& 2264; MCCorMTCK, Evidence 264 (1954). There are a number of exceptions to this rule. See Shapiro v. United States, 335 U.S. 1 (1948). Dr. Thayer's records did not fall within any of these exceptions. Petition for Hearing for the People, People v. Thayer, 63 Cal. 2d 635, 408 P.2d 108, 47 Cal. Rptr. 780 (1965), pp. 17-18.

24 Opening Brief for the Defendant, People v. Thayer, 44 Cal. Rptr. 718 (1965) (vacated), pp. 11-25.

25 People v. Thayer, 44 Cal. Rptr. 718 (1965) (vacated).

2663 Cal. 2d at 639-40, 408 P.2d 110-11, 47 Cal. Rptr. 782-83.

${ }^{27}$ Id. at 642,408 P.2d at 112,47 Cal. Rptr. at 784. 
is clear that the heart of the opinion is the dicta rejecting the mere evidence rule. ${ }^{28}$

Before turning to a closer analysis of Chief Justice Traynor's reasons for rejecting the inere evidence rule and the implications this rejection will have for future development of the law, it is necessary to review the early history of the rule.

\section{II}

THE HISTORY OF THE MERE EVIDENCE RULE

In 1917 Congress enacted the first general statute authorizing the issuance of search warrants to federal officers. ${ }^{29}$ This statute is presently codified in Rule 41(b) of the Federal Rules of Criminal Procedure, which provides:

A warrant may be issued under this rule to search for and seize any property

(1) Stolen or embezzled in violation of the laws of the United States; or

(2) Designed or intended for use or which is or has been used as the means of committing a criminal offense ....

The language employed in this statute reflects common law principles, ${ }^{30}$ and recourse must be had to the landinark case of Entick v. Carrington ${ }^{31}$ to understand their significance.

\section{A. The Antecedents of the Rule}

For the purpose of gathering evidence to prosecute Entick for seditious libel, Lord Halifax, the Secretary of State, issued a general warrant for the searcli and seizure of Entick's papers. ${ }^{32}$ Lord Camden, in an action

28 Thayer has been cited as holding that the mere evidence rule is not applicable in California. People v. Potter, 240 A.C.A. 687, 697, 49 Cal. Rptr. 892, 898-99 (1966); Elder v. Board of Medical Examiners, 241 A.C.A. 343, 361, 50 Cal. Rptr. 304, 318 (dictum), petition for cert. filed, 35 U.S.L. WeEK 3106 (U.S. Oct. 4, 1966) (No. 464). There is also internal evidence in the opinion that the rejection of the mere evidence rule is the real significance of the case. Chief Justice Traynor devotes only a brief paragraph to the discussion of the instrumentality exception and its apphication to the facts of the case. If the lower courts were expected to apply the instrumentality exception, sound judicial administration would require that the supreme court lay out its reasoning so that the lower courts would have guidelines in what is an unusually difficult area of the law. Chief Justice Traynor also points out that the instrunentality exception has all but destroyed the rule. $63 \mathrm{Cal}$. $2 \mathrm{~d}$ at 640,408 P.2d at 111,47 Cal. Rptr. at 783.

29 Act of June 15, 1917, ch. 30, tit. xi, 40 Stat. 228; Kaplan, Search and Sezzure: A NoMan's Land in the Criminal Laz, 49 CaLIF. L. RIv. 474, 477 (1961).

30 The term "common law" is used here in its restricted sense, namely, the law applied by the conimon law courts of England. See generally LANDYNSKx, SEARCH AND SEIZURE AND THE SUPREME CoURT 20-30 (1966).

3119 How. St. Tr. 1029 (1765).

32 LANDYNSKI, op. cit. supra note 30 , at 27-29. 
for trespass brought by Entick, held that the search and seizure were unlawful. The major premise of Lord Camden's argument, in keeping with the spirit of the age, was as follows: "The great end for which men entered into society was to secure their property .... Papers are the owner's goods and chattels; they are his dearest property; and are so far from enduring a seizure, that they will hardly bear an inspection . . .."33 Lord Camden rejected the defendant's contention that the search and seizure in question were supported by the admitted legality of such a procedure in the case of stolen goods. He noted that a seizure of stolen goods differed from the seizure in question because the owner, at the risk of an action in trespass if he were mistaken, could swear out a warrant to recover his own property. In the case at bar, the defendant was asserting the power to seize the property of another ${ }^{34}$ In addition to stolen goods, other kinds of property subject to seizure were goods on which taxes had not been paid and goods forfeitable because of the use to which they had been put. In both cases, the owner lost his right to possession and therefore the goods were subject to seizure. ${ }^{35}$

The next development of consequence was the decision of the United States Supreme Court in Boyd v. United States, ${ }^{36}$ the first important case to deal with the fourth amendment. ${ }^{37}$ The government sought the forfeiture of certain goods which it contended the Boyds had imported in violation of the law. The issue was whether the government could require the defendants to produce an invoice for the goods by means of a subpoena. ${ }^{38}$ While this was a singularly inauspicious factual situation for a discussion of the fourth amendment, ${ }^{33}$ Justice Bradley argued that the compulsory production of a man's private papers was within the scope of the fourth amendment because it "effects the sole object and purpose of a search and

3319 How. St. Tr. 1029, quoted in Boyd v. United States, 116 U.S. 616, 627-28 (1886).

34 Ibid.; Kaplan, supra note 29, at 475 .

$35 \mathrm{Ibid}$.

36116 U.S. 661 (1886). See generally LANDYNSKI, op. cit. supra note 30, at 49-61.

37 See LaNdYNSKI, op. cit. supra note 30 , at 49.

38116 U.S. at 618.

${ }^{39}$ In a concurring opinion Justice Miller, joined by Chief Justice Waite, argued that the fifth amendment's privilege against self-incrimination was sufficient to dispose of the issues in the case. 116 U.S. at 639 . While it is not clear why Justice Bradley found it necessary to discuss the fourth amendment, two factors may have prompted this discussion. First, until shortly before the case at bar, the statute had provided that the proper method for obtaining evidence of violations was by a search rather than by compulsory production under a subpoena. The Court may have wished to cast doubt on the legality of the broad power to search which had previously been granted by the statute. See id. at 621 . Second, and more likely, the Court may have felt uneasy over applying the fifth amendment's privilege against self-incrimination to documents. See $i d$. at 636; see note 23 supra. Thus, the fourth amendment could have been invoked to bolster the Court's argument concerning the fifth. This suggestion finds some support in Justice Bradley's insistence that the use of a subpoena in these circunstances is essentially the same as a search. See $i d$. at 622 . 
seizure. ${ }^{40}$ Having established the applicability of the fourth amendment, he argued that a search and seizure was unreasonable because of the nature of the property involved. He recognized the legitimacy of a search for and seizure of stolen goods or articles which it is unlawful for a person to possess; ${ }^{41}$ but he held that the rule for stolen goods did not provide authority for the seizure in the case at bar because "in the one case, the government is entitled to the possession of the property; in the other it is not."42 Justice Bradley placed considerable rehance on Entick v. Carrington simce "it may be confidently asserted that its propositions were in the minds of those who framed the Fourth Amendment . . . and were considered as sufficiently explanatory of what was meant by unreasonable searclies and seizures."43

\section{B. The Zenith of the Rule: Gouled v. United States}

These developments were followed by the decision in Gouled v. United States $^{44}$ _the leading case in the establishment of the mere evidence rule. Gouled was accused of attempting to defraud the United States and of using the mails to defraud. ${ }^{45}$ Pursuant to a searcli warrant, the government seized an unexecuted form contract, a written contract signed by the defendant and one Steinthal, and a bill from Gouled's attorney. ${ }^{46}$ As required by the statute, the affidavits in support of the warrant characterized the property souglit as instrumentalities of the crimes alleged. ${ }^{47}$ The Court held that the papers were seized in violation of the fourth amendment and that their admission in evidence violated the fifth amendment. ${ }^{48}$ Justice Clarke observed that it was clear from the wording of the fourth amendment that searcli warrants were recognized when the Con-

$40 \mathrm{Id}$. at 622 .

41 Id. at $623-24$.

42 Id. at 623 .

43 Id. at $626-27$

44255 U.S. 298 (1921).

$45 \mathrm{Id}$. at $302-03$.

46 Id. at 306-07.

47 The first affidavit characterized the property described as "a means of committing a felony ...."Id. at 307. The second affidavit characterized the property seized as having "been used in the commission of a felony ...." Ibid. The statute permits the seizure of property "which is or has been used as the means of committing a criminal offense . . .." Fed. R. Crecr. P. 41(b) (2). See note 29 supra and accompanying text.

48 Id. at 310-11. The argument that the admission of evidence seized in violation of the fourth amendment is a violation of the fifth amendment is not the generally accepted rationale for the exclusionary rule. Mapp v. Ohio, 367 U.S. 643 (1961); Weeks v. United States, 232 U.S. 383 (1914). However, this theory appears in some of the early cases. E.g., Agnello v. United States, 269 U.S. 20, 33-34 (1925); Gouled v. United States, 255 U.S. 298, 311 (1921). It also appears in Justice Black's concurring opmion im Mapp v. Ohio, supra at 661-62. It sbould be noted, however, that Justice Black's vote was necessary for a holding that the exclusionary rule applied to the states. 
stitution was adopted. However, their use was limited to "stolen or forfeited property, or property liable for duties and concealed to avoid payment of them, excisable items and books required by law to be kept with respect to them, counterfeit coin, burglars' tools and weapons, implements of gambling 'and many other things of like character.' "40 The rationale underlying this limitation is that a search warrant may only issue

when a primary right to such search and seizure may be found in the interest which the public or the complainant may have in the property to be seized, or in the right to the possession of it, or when a valid exercise of the police power renders possession of the property by the accused unlawful and provides that it may be taken..$^{50}$

The Court relied primarily on Boyd to support its analysis and made only passing reference to the statute. ${ }^{51}$ Gouled departed from the language, if not the spirit, of Boyd and Entick. ${ }^{52}$ Although the Court found that the papers at issue were mere evidence, ${ }^{53}$ it noted that "there is no special sanctity in papers ... to render them immune from search and seizure" if they fall within the general rules applicable to other forms of property.

The decision in Gouled represents the zenith of the mere evidence rule. The subsequent cases become increasingly embroiled in exceptions to the rule. This problem is imphicit in the residual nature of mere evidencethat which is neither contraband nor instrumentality nor fruit of a crime. $^{55}$ The exception for instrumentalities of crimes has caused the major portion of the difficulty. ${ }^{56}$

The source of this difficulty with the mere evidence rule is a shift in emphasis in society's view of the nature of fundamental rights. The earlier property-based concept which found expression in Entick and Boyd is no longer felt to be satisfactory. Rather, in Chief Justice Traynor's words, "the modern view . . . is that the exclusionary rules of evidence exist primarily to protect personal rights rather than property interests and that common law property concepts are usually irrelevant." ${ }^{\prime 57}$ However difficult

\footnotetext{
49 Gouled v. United States, supra note 48 , at 308.

50 Id. at 309.

51 See id. at 303, 310, 311.

52 See text accompanying note 33 supra.

53255 U.S. at 310-11. The test used was whether the government would "have the right to take it into its possession to prevent injury to the public from its use." Id. at 310 . 54 Id. at 309.

55 See 8 WIGASORE \& 2184a, at 45, quoted in text accompanying note 5 supra.

56 See Note, 54 Gro. L.J. 593, 609-14 (1966); e.g., Abel v. United States, 362 U.S. 217 (1960) (birth certificates, bankbook, coded message held instrumentalities of the crinic of espionage); United States v. Lefkowitz, 285 U.S. 452 (1932) (business records, correspondence and utility bills held not instrumentalities of conspiracy to violate Volstead Act); Marron v. United States, 275 U.S. 192 (1927) (business records and utility bills held instrumentalities of conspiracy to violate Volstead Act).

5763 Cal. 2d at 637-38, 408 P.2d at 109, 47 Cal. Rptr. at 781.
} 
the determination of whether a particular item is an instrumentahity when the test is based on property notions, ${ }^{58}$ the difficulty is magnified when this test is no longer available. ${ }^{59}$ This theoretical difficulty can be illustrated by viewing the question of seizability along a continuum rather than as an either-or proposition. At the contraband-fruit end of the continuum, the property is clearly seizable. At this end we are closest to the earlier property-based notions. At the mere evidence end, the property is clearly not seizable. Instrumentalities lie in the middle area, shading into contraband at one end and into mere evidence at the other. In such a situation there are two predictable developments. First, the lack of easily discernible boundaries to the instrumentality exception and the pressures on the courts to admit reliable probative evidence make it all but inevitable that the category of instrumentality will expand. Second, to the degree the rule is not swallowed by the exception, the lack of rational distinctions between the protected and unprotected classes of property will allow factors other than the cliaracter of the item seized to determine the application of the rule.

\section{The Erosion of the Rute}

In Marron v. United States, ${ }^{60}$ six years after the decision in Gouled, the first of these developments became evident. Federal prohibition agents obtamed a search warrant to search premises in whicl a saloon was being run in violation of the Volstead Act. ${ }^{61}$ The agents entered the premises, arrested a co-defendant and conducted a search. They found large quantities of intoxicating liquors in a closet. While in the closet, they discovered a ledger containing inventories, receipts and expenses. ${ }^{62}$ Beside a casl register they found bills addressed to the defendant for gas, electricity, water and telephone. The agents seized these bills and the ledger even though the warrant only authorized the search for and seizure of intoxicating liquors and articles for their manufacture. ${ }^{63}$ The Court held that even though the bills and ledger could not be seized under the warrant because of the requirement that the items to be seized must be particularly described, ${ }^{64}$ the seizure was lawful because the officers ar-

58 The early opinions do not evidence any difficulty with the classification of the kinds of property subject to forfeiture and hence to seizure. E.g., Gouled v. United States, 255 U.S. 298, 309-11 (1921); Boyd v. United States, 116 U.S. 616, 623 (1886); People v. Chiagles, 237 N.Y. 193, 196-97, 142 N.E. 583, 584 (1923).

59 See United States v. Poller, 43 F.2d 911, 913-14 (2d Cir. 1930); United States v. Kirschenblatt, 16 F.2d 202, 204 (2d Cir. 1926).

60275 U.S. 192 (1927).

61 National Prohibition Act (Volstead Act) ch. 85, 41 Stat. 305 (1919).

62275 U.S. at 194.

$63 I d$, at 193.

$64 I d$. at 196. 
rested Marron's co-defendant in the act of committing a crime--conspiracy to violate the Volstead Act-and could search the premises incident to that arrest. ${ }^{65}$

In answer to the contention that the ledger and utility bills were mere evidence and hence immune from seizure even if the search was lawful, the Court argued that the ledger was "a part of the outfit or equipment actually used to commit the offense" even if it was "not as essential to the maintenance of the estabhshment as were bottles, hquors, and glasses." The Court said that the utility bills were "convenient, if not in fact necessary, for the keeping of the accounts; and, as they were so closely related to the business, it is not unreasonable to consider them as used to carry it on." ${ }^{267}$ These definitions could be himited to the facts of the case and read as applicable only in circumstances where the business enterprise is criminal in its very nature. However, if stress is placed upon the characterization of the utility bills as "convenient," it would be difficult to conceive of a state of facts in which an item of evidentiary significance would not be at least convenient to the commission of the crime. ${ }^{68}$

The next important case-United States v. Lefkowitz ${ }^{00}$-illustrates the second development pointed out above. Lefkowitz is the only Supreme Court case to exclude evidence on the authority of Gouled. Lefkowitz and his co-defendant were charged with a conspiracy to violate the Volstead Act by running a wholesale hiquor business. ${ }^{70}$ Prohibition agents acting pursuant to an arrest warrant arrested Lefkowitz in his office. The agents then searched the office and seized a large quantity of books, papers, and other articles. ${ }^{71}$ Among these articles were business records, unmailed correspondence, completed order shps, and hight bills. ${ }^{72}$

The Court held that the items seized were mere evidence and "could not lawfully be searched for and taken even under a search warrant issued upon ample evidence and precisely describing such things and disclosing exactly where they were." 73 This case cannot be reconciled with Marron in terms of the classifications of property found in the mere evidence rule. The crime in the two cases is the same, namely, conspiracy to violate the Volstead Act. Although not everything seized in Lefkowitz's office could

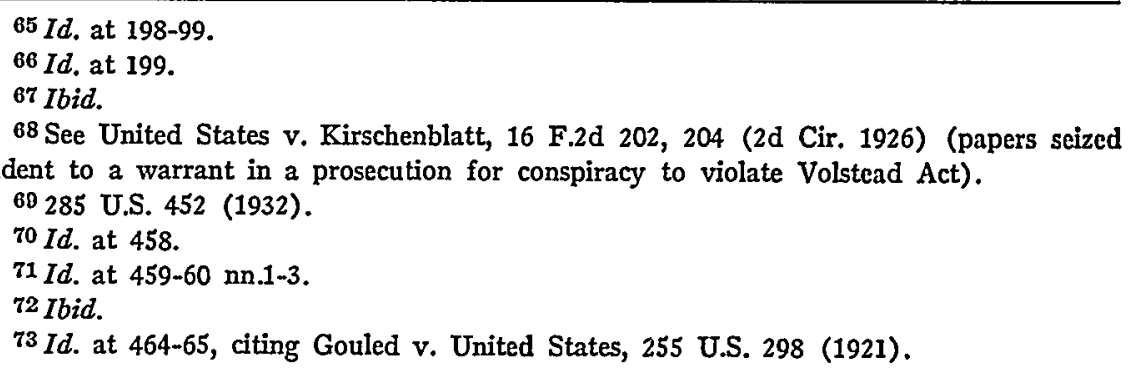


be fitted easily into the broad definitions in $\mathrm{Marron}^{74}$ those definitions would seem to encompass all the items which would have had evidentiary significance. ${ }^{75}$ The Court does point out one factual distinction between the cases. In Marron there was a crime being committed in the presence of the officers-the maintenance of a public nuisance-while this was not the case in Lefkowitz. However, this would only affect the lawfulness of the underlying arrest, and the Court in Lefkowitz found nothing wrong with the arrest pursuant to the warrant. ${ }^{76}$

The situation envisioned by the Lefkowitz opinion ${ }^{77}$ arose in Foley $v$. United States ${ }^{78}$ one year later. Foley was accused of a conspiracy to violate the Volstead Act by operating a wholesale hquor business. Federal agents tapped Foley's telephone and, on the basis of the information thus obtained, secured a search warrant elaborately describing the items to be seized. ${ }^{79}$ The items seized pursuant to this warrant included books of unfilled orders, ledgers of customers' accounts, an adding mnachine and a typewriter. The court held that these items were not mere evidence. Lefkowitz was distinguished on the ground that it "involved a forcible exploratory search dependent on an arrest." 180

It is reasonably clear that the exclusion of evidence in Lefkoreitz did turn on the fact that it was the product of an overly broad search rather than on the fact that the nature of the property made it immune from seizure. It is only in terms of the character of the searches in the two cases that Marron and Lefkowitz can be reconciled. In Lefkowitz the Court attempted to distinguish Marron by pointing out that no search was conducted because the bills and ledger were in plain view. ${ }^{81}$ The search conducted in Lefkowitz was described as "unrestrained"

74 Among the items seized were a stenographer's textbook, a bottle of alcohol not shown to be fit for drinking, and a blank order book. It is difficult to conceive of these as even convenient for the commission of the crime. On the other hand, they would have virtually no evidentiary value.

75 Names and addresses of customers, if not necessary to conduct a mail order business, are at least convenient. It is difficult to see how the utility bills can be convenient to Marron's retail busimess and not convenient to Lefkowitz's wholesale business. The correspondence with customers informing them of the yearly change of name seems to be closer to the bottles and glasses mentioned in Marron than to anything else, and the same seens to be true of the filled-out order slips.

76285 U.S. at $462-63$.

77 Justice Butler suggested that the papers seized in Lefkowitz could not be lawfully seized even if a search warrant had been issued which was supported by ample evidence, precisely described the articles to be seized, and disclosed their exact location. Id. at 464-65.

7864 F.2d 1 (5th Cir.), cert. denied, 289 U.S. 762 (1933).

$70 I d$, at 2 .

$89 \mathrm{Id}$. at 4 .

81285 U.S. at 465 .

82 Id. at 464. 
tory and general."183 Further, the Court cited Go-Bart Importing Co. v. United $_{\text {States }}{ }^{84}$ as controlling. ${ }^{85}$ Go-Bart turned on the legality of the search $^{86}$ and not on the mere evidence rule. Marron was distinguished from the situation in Go-Bart, insofar as it was relevant to Lefkowitz, by the fact that in Marron there was no "general search or rummaging of the place." ${ }^{\prime 87}$ Finally, the Lefkowitz opinion suggested that the arrest may have been a pretext to search for evidence. ${ }^{88}$

Chief Justice Traynor suggests that Lefkowitz and Marron set the pattern for the subsequent development of the mere evidence rule. ${ }^{80}$ This assertion is substantially correct. Where the circumstances surrounding the search have not suggested an exploratory search, the property seized has generally been characterized as an instrumentality of a crime. ${ }^{00}$ On the other hand, where the search has appeared overly broad, the courts have of ten resorted to the mere evidence rule as a basis for holding the evidence inadmissible rather than taking the more direct approach of declaring it inadmissible as the product of an illegal search. ${ }^{01}$ This use of the instrumentality exception may serve as a means of affording rough justice in individual cases, but the approach renders the mere evidence rule almost useless as a means of analyzing the decisions invoking it. ${ }^{22}$

83 Id. at 465 .

84282 U.S. 344 (1931).

85285 U.S. at 462.

86282 U.S. 344, 357-58 (1931).

87 Id. at 358.

88285 U.S. at 467 .

$8963 \mathrm{Cal} .2 \mathrm{~d}$ at $641,408 \mathrm{P} .2 \mathrm{~d}$ at $112,47 \mathrm{Cal}$. Rptr. at 784.

00 See, e.g., Marron v. United States, 275 U.S. 192 (1927); Smith v. United States, 321 F.2d 427 (9th Cir. 1963); United States v. Boyette, 299 F.2d 92 (4th Cir.), cert. denied, 369 U.S. 844 (1962); Matthews v. Correa, 135 F.2d 534 (2d Cir. 1943); Foley v. United States, 64 F.2d 1 (5th Cir.), cert. denied, 289 U.S. 762 (1933). However, this is not always the case. The nere evidence rule was invoked in one case where there could be no question about the search being valid since it was conducted by customs officers who have a plenary power to search. Takahashi v. United States, 143 F.2d 118 (9th Cir. 1944).

91 See, e.g., United States v. Leikowitz, 285 U.S. 452 (1932); Morrison v. United States, 262 F.2d 449 (D.C. Cir. 1958); United States v. Thomson, 113 F.2d 643 (7th Cir. 1940); Bushouse v. United States, 67 F.2d 843 (6th Cir. 1933). However, this is not always the case. The Court found the property seized in Abel v. United States, 362 U.S. 217 (1960), to be instrumentalities of the crime of espionage despite the somewhat dubious character of the search. Cf. Harris v. United States, 331 U.S. 145 (1947). On the other hand, in some cases the seizure of a large amount of questionable material has led the Court to invalidate the search itself. See, e.g., Kremen v. United States, 353 U.S. 346 (1957) (per curiam).

92 See State v. Bisaccia, 45 N.J. 504, 517-18, 213 A.2d 185, 192-93 (1965); State v. Chinn, 231 Ore. 259, 285-86, 373 P.2d 392, 404-05 (1962) (O'Connell, J. dissenting); Note, 54 Gro. L.J. 593, 609-14 (1966); Comment, 20 U. Crr. L. Rev. 319, 320 \& n.20 (1953). Compare Marron v. United States, 275 U.S. 192 (1927), and Foley v. United States, 64 F.2d 1 (5th Cir.), cert. denied, 289 U.S. 762 (1933), with United States v. Lefkowitz, stipra note 91, and Bushouse v. United States, supra note 91. Compare State v. Chinn, supra (beer bottles, soiled sheets, and a camera instrumentalities of the crime of statutory rape), with 
Insofar as exclusionary rules are designed to control the out-of-court conduct of law enforcement officers, ${ }^{93}$ this state of affairs presents more than a merely analytic problem because conduct cannot be conformed to rules which cannot be understood. ${ }^{94}$

However, there is one sense in which Marron and Lefkowitz do not reflect the pattern of the subsequent cases. As Chief Justice Traynor argues, the trend has been to broaden the definition of instrumentality to the point where it all but vitiates the rule. ${ }^{95}$ In 1923 Judge Cardozo, in the course of an opinion rejecting the application of the mere evidence rule to searches of the perscn ${ }^{96}$ gave two examples of kinds of evidence immune from seizure under the rule: letters between conspirators and the garments of a murderer. ${ }^{97} \mathrm{It}$ is now reasonably clear that the majority of courts would not hold that clothing worn during the commission of a crime is immune from seizure..$^{98}$ Further, a memorandum containing a list of watcli movements has been held to be an instrumentality of the crime of smugging watches. ${ }^{99}$ In a prosecuticn for procuring the interstate transportation of a woman for the purposes of prostitution, a restaurant guest check with the notation " $\$ 5.00$ " has been held to be subject to seizure on the theory that it was the instrumentality of the crime of running a house of prostitution. ${ }^{100}$ Finally, some beer bottles, soiled sheets, and a camera containing exposed film have been held instrumentalities of the crime of statutory rape. ${ }^{101}$ It is submitted that any definition drawn

Morrison v. United States, supra note 91 (a soiled handkerchief not an instrumentality of the crime of sodomy). Compare United States v. Guido, 251 F.2d 1, 3-4 (7th Cir.), cert. denied, 356 U.S. 950 (1958) (sloes held an instrumentality), with Williams v. Umited States, 263 F.2d 487, 488 (D.C. Cir. 1959) (dictum), cert. deried, 365 U.S. 856 (1961) (clothing not an instrumentality).

93 See Mapp v. Ohio, 367 U.S. 643, 651-53 (1961); People v. Cahan, 44 Cal. 2d 434, 445, 282 P.2d 905, 911 (1955).

94 FULLER, THE MORALITY OF LAW 63-65 (1964).

9563 Cal. $2 \mathrm{~d}$ at 640,408 P.2d at 111, 47 Cal. Rptr. at 783.

96 The mere evidence rule has never been applied to searches of the person. United States v. Kraus, 270 Fed. 578, 582 (S.D.N.Y. 1921) (L. Hand, J.), citing Weeks v. United States, 232 U.S. 383, 392 (1914); People v. Chiagles, 237 N.Y. 193, 195, 142 N.E. 583 (1923); 1 Varon, Searches, SeizUres, and IMmunities 104 (1961).

97 People v. Chiagles, supra note 96 (1923).

98 See Stoner v. California, 376 U.S. 483 (1964); United States v. Guido, 251 F.2d 1 (7th Cir.), cert. denied, 356 U.S. 950 (1958); Morton v. United States, 147 F.2d 28 (D.C. Cir.), cert. denied, 324 U.S. 857 (1945); United States v. Margeson, 246 F. Supp. 219 (S.D. Maine 1965) (dictuni). However, the history of the mere evidence rule does not make for confidence in the certainty of prediction. Compare Morton v. United States, supra, with Williams v. United States, 263 F.2d 487, 488 (D.C. Cir. 1959) (dictum), cert. denied, 365 U.S. 856 (1961). See note 92 supra and accompanying text.

${ }^{99}$ Landau v. United States Attorney, 82 F.2d 285 (2d Cir.), cert. denied, 298 U.S. 665 (1936).

100 United States v. Boyette, 299 F.2d 92 (4th Cir.), cert. denied, 369 U.S. 844 (1962). 101 State v. Chinn, 231 Ore. 259, 373 P.2d 392 (1962). 
from these cases would amount to saying that anything which plausibly connects the defendant with a crime is an instrumentality. ${ }^{102}$

The treatment accorded the mere evidence rule by the Supreme Court supports Chief Justice Traynor's contention ${ }^{103}$ that the rule is not a fundamental constitutional standard. ${ }^{104}$ First, the expansion of the instrumentality exception is not consistent with the liberal construction appropriate to constitutional standards. ${ }^{105}$ The fact that the "rule has been distinguished nearly out of existence"106 casts considerable doubt on its status as one of "the 'fundamental criteria' laid down by the Fourth Amendment and in opinions of ... [the Supreme] Court applying that Amendment." 107 Second, the Court has not excluded evidence solely on the authority of the mere evidence rule since the decision in Gouled. ${ }^{108}$ Third, the continued reference to the rule by the Court can be explained by the existence of the federal statute. ${ }^{109}$ However, given the United States Supreme Court's concern for the rights protected by the fourth and fifth amendments, ${ }^{110}$ the question remains whether the rule announced

102 For an item to be subject to seizure it is not necessary that it be an instrumentality of the crime which underlies either the warrant or the arrest supporting the search. It is sufficient that the item be the instrumentality or fruit of any crime. Abel v. United States, 362 U.S. 217, 237-40 (1960); Harris v. Umited States, 331 U.S. 145, 154-55 (1947). However, if the arrest or search warrant is a mere pretext to gain access to search for evidence of other crimes, the search itself may be condemned as exploratory. People v. Schaumloffel, 53 Cal. 2d 96, 346 P.2d 393 (1959) (per curiam); Yonchar v. Superior Court, 193 Cal. App. 2d 135, 14 Cal. Rptr. 93 (1961); People v. Mills, 148 Cal. App. 2d 392, 306 P.2d 1005 (1957). The language in both People v. Schaumloffel, supra at 100-01, 346 P.2d at 395-96, and Yonchar v. Superior Court, supra at 137, 14 Cal. Rptr. at 95, sounds very much like the mere evidence rule. Further, the operation of the California rule is much stricter than the federal rule. Compare Yonchar v. Superior Court, satpra, with United States v. Boyette, 299 F.2d 92 (4th Cir.), cert. denied, 369 U.S. 844 (1962).

$10363 \mathrm{Cal}$. 2d at 642 , 408 P.2d at 112, 47 Cal. Rptr. at 784.

104 Cf. Gideon v. Wainwright, 372 U.S. 335, 350-51 (1963) (Harlan, J. concurring).

105 See Ker v. California, 374 U.S. 23, 33 (1963), quoting Go-Bart Importing Co. v. United States, 282 U.S. 344, 357 (1931).

10663 Cal. 2d at 640, 408 P.2cl at 111, 47 Cal. Rptr. at 783.

107 Ker v. California, 374 U.S. 23, 33 (1963).

108 The assumption made here is that United States v. Lefkowitz, 285 U.S. 452 (1932), can be explained in terms of an illegal search rather than as an invocation of the mere evidence rule. See notes 80-88 supra and accompanying text.

109 FED. R. CRRM. P. 41(b). The relevance of this statute to the continued concern with mere evidence in the federal cases where a search warrant has been issued is clear. In the case of a search incident to a lawful arrest, the assumption has always been made that the search can be no broader than that authorized under a warrant. United States v. Lefkowitz, 285 U.S. 452, 464 (1932). It is not illogical to argue that searches without a warrant should be no broader than those under a warrant to avoid encouraging law enforcement officers to conduct searches without obtaining a warrant. Cf. Aguilar v. Texas, 378 U.S. 108, 110-11 (1964). Such a policy decision would be a proper exercise of the Court's supervisory powers. See Mapp v. Ohio, 367 U.S. 643, 682 (1961) (Harlan, J. dissenting).

110 See, e.g., Miranda v. Arizona, 384 U.S. 436 (1966); Malloy v. Hogan, 378 U.S. 1 (1964); Stoner v. California, 376 U.S. 483 (1964). 
by Gouled or some modified version of it might yet find favor with the Court because it protects these rights. In other words, the question remains whether the rejection of the mere evidence rule necessarily carries with it a rejection of all limitations on seizure as distinguished from search.

\section{III}

THE PERFORMANCE OF THE MERE EVIDENCE RULE

Proponents of the rule generally offer two sets of constitutional rights which they assert require the unique protection afforded by the mere evidence rule. For purposes of identification these can be termed the right of privacy and the right to be free from compulsory self-incrimination. ${ }^{111}$ Chief Justice Traynor argues forcefully that the mere evidence rule does not in fact protect these rights in any coherent manner. ${ }^{112}$ However, since he confines his discussion to the standard form of the rule, ${ }^{113}$ it is necessary to analyze the possible relation of these rights to limitations on the power of the governinent to seize property.

\section{A. The Protection of the Right of Privacy}

There have been two theories advanced to justify the mere evidence rule as a means of protecting the right of privacy. The older and more general theory is that the rule provides protection against exploratory searches which are admittedly invasions of privacy. As was pointed out above, the inere evidence rule has been invoked as the basis for excluding evidence in situations where the scope of the search exceeded proper bounds. ${ }^{114}$ In Gouled, the Court argued that issuance of search warrants was restricted to property of a certain nature so that warrants might "not be used as a means of gaining access to a man's house or office and papers solely for the purpose of making [a] search to secure evidence to be used against hin ...."115 This concern with the use of a search as an investigative technique runs like a leitmotif through the cases discussing the mere evidence rule. ${ }^{116}$ However, as Chief Justice Traynor suggests, the diff-

111 The privacy argument is generally found in the older cases. See, e.g., Harris v. United States, 151 F.2d 837, 840 (10th Cir. 1945), af'd, 331 U.S. 145 (1947); United States v. Kirschenblatt, 16 F.2d 202, 203-04 (2d Cir. 1926). The privilege against self-incrimination is invoked in nuore recent arguments in justification of the rule. See, e.g., United States v. Boyette, 299 F.2d 92, 95 (4th Cir.), cert. denied, 369 U.S. 844 (1962); Manwaring, California and the Fourth Amendment, 16 Stan. L. Rev. 318, 328 (1964); Note, 54 GEo. L.J. 593, 605-06 (1966).

11263 Cal. 2d at 638-39, 408 P.2d at 110, 47 Cal. Rptr. at 782.

113 See text accoinpanying note 5 sulpra.

114 See note 91 supra and accompanying text.

115255 U.S. at 309.

116 See cases cited in note 91 supra. 
culty with this justification of the rule is that "if ... [this] is the purpose of the rule, it is certainly not its effect. The rule does not prevent exploratory searches at all; it prevents the seizure of mere evidence in the course of any search ...."117 In other words, the rule is both overinclusive and underinclusive. It prohibits the seizure of mere evidence no matter how precise the search. But if the property seized falls within one of the exceptions, the rule, in and of itself, does not bar the most exploratory of searches. Further, the expansion of the instrumentality exception has severely limited whatever incidental protection the rule might have offered against exploratory searches.

However, there is one kind of seizure in which the underlying property-right rationale of the mere evidence rule retains its validity. Ordinarily, the individual from whom property is seized has no substantial pecuniary interest in the articles seized. Fis interest in the property relates to the use it may have in estabhishing his guilt at trial. However, there are circumstances in which an individual's interests are invaded quite apart from the potential evidentiary value of the materials. For example, if the government should seize the entire contents of an office ${ }^{118}$ from an individual who has an on-going business, the individual could experience serious hardship. The mere evidence rule should, in theory, prohibit such wholesale seizures. ${ }^{119}$

A more modern and specialized version of the assertion that the mere evidence rule protects the right of privacy is the theory that the rule protects private papers. ${ }^{120}$ While the mere evidence rule cases have tended to permit the seizure of papers of one sort or another more often than not, ${ }^{121}$ the courts have evidenced uneasiness at the prospect of applying their broad definitions of instrumentalities of a crime to private papers. ${ }^{122}$

11763 Cal. 2d at 638, 408 P.2d at 110, 47 Cal. Rptr. at 782.

118 See Flagg v. United States, 233 Fed. 481 (2d Cir. 1916).

110 However, this protection is not provided in practice. See Leahy v. United States, 272 F.2d 487, 491 (9th Cir. 1959): "There is nothing in the record to indicate that the arrest was merely a pretext for the purpose of conducting a general exploratory search for inerely evidentiary materials . . . The revenue agents . . . seized an adding machine, a telephone, record books, receipts, pencils, pens, money, and the keys to safety deposit boxes, as well as a number of rifles, shotguns and pistols. It is clear from the items seized that the search was specifically directed to the instrumentalities used in the commission of the crime of unlawfully engaging in the business of wagering."

120 See Shellow, The Continuing Vitality of the Gouled Rule: The Search for and Seizure of Evidence, 48 MaRq. L. REv. 172, 179 (1964); Comment, 59 Nw. U.L. REv. 611, 628 (1964).

121 E.g., Abel v. United States, 362 U.S. 217 (1960); Harris v. United States, 331 U.S. 145 (1947); United States v. Stern, 225 F. Supp. 187 (S.D.N.Y. 1964).

122 Abel v. United States, supra note 121, at 236; Harris v. United States, sttpra note 121, at 154; United States v. Boyette, 299 F.2d 92, 95 (4th Cir.), cert. denied, 369 U.S. 844 (1962); Umited States v. Kirschenblatt, 16 F.2d 202, 203-04 (2d Cir. 1926); People v. 
But, as Chief Justice Traynor points out, ${ }^{123}$ the mere evidence rule has not been read as protecting private papers as such. ${ }^{124}$

There are at least two explanations for the recurring concern over private papers. The first is the nature of the search involved in uncovering papers which are probative of guilt. It was this aspect of the problem which troubled Judge Learned Hand. He argued that papers evidencing guilt "cannot be reached, except by a thorough search of all that the offender has, ... [ [and to allow this] would be to countenance exactly what the [fourth] amendment was designed to prevent."125 The instrumentality exception was not a serviceable check on the potential invasion of privacy involved because "if all records of the offender's doings ... are to be included [in the definition of instrumentality], there would seem to be no escape from allowing a search at large through all his papers." ${ }^{126}$ For this reason, Judge Hand argned that the power to seize papers should be hinnited to "those which are a part of the forbidden act itself." $127 \mathrm{He}$ refused to attempt to define this concept, but gave as examples of what he had in mind "the forged note, the fraudulent prospectus, the policy slip, the written contract ... perhaps all these may be contraband and subject to seizure ...."128 On the other hand, "the whole of a man's correspondence, his books of account, the record of his business, in general, the sum of his documentary property-these, in our judgment, are . . . inviolate . ..."129

A second source of the concern exhibited by courts over the seizure of private papers is the nature of the articles seized. Private papers, be they diary or political tract, ${ }^{130}$ are felt to stand on a different footing from

Thayer, 63 Cal. 2d 635, 642-43, 408 P.2d 108, 112-13, 47 Cal. Rptr. 780, 784-85 (1965), cert. denied, 384 U.S. 908 (1966); State v. Bisaccia, 45 N.J. 504, 515-16, 213 A.2d 185, 191 (1965).

12363 Cal. $2 \mathrm{~d}$ at 638,408 P.2d at 110, 47 Cal. Rptr. at 782 .

124 This statement is correct insofar as the present state of the law can be determined. The courts have not yet dealt, in mere evidence terms, with the private diary problem alluded to in United States v. Boyette, 299 F.2d 92, 95 (4th Cir.), cert. denied, 369 U.S. 844 (1962).

125 United States v. Kirschenblatt, 16 F.2d 202, 204 (2d Cir. 1926).

120 Ibid.

127 Ibid.

128 Ibid.

$129 \mathrm{Ibid}$. Judge Hand considered the views expressed in this opinion overruled by Marron. United States v. Poller, 43 F.2d 911, 913 (2d Cir. 1830).

130 One difficulty with the term "private papers" lies in the determination of what distinguishes a "private" paper from the more general class of papers. Tlie United States Supreme Court las recognized that there is a distinction: "The word 'books' in the context of a phrase like 'books and records' has, of course, a quite different meaning. A 'book' which is no more than a ledger of an unlawful enterprise thus might stand on a quite different constitutional footing from the [political and philosophical] books involved in the present case." Stanford v. Texas, 379 U.S. 476, 485 n.16 (1965). Compare Chief Justice Traynor's discus- 
other kinds of personal property. This difference can be attributed at least in part to the fact that they are products of the mind; to invade this realm is to strip the individual of the last vestige of privacy. Should the document seized have any political, religious, or artistic significance, the first amendment is added to reinforce the feeling that sucli invasion is improper. ${ }^{131}$

Accepting as correct Chief Justice Traynor's contention that the mere evidence rule, in its present form, does not protect the individual's privacy, there remains the question whether any restriction on seizure is necessary to protect this right. Beginning with the first authoritative construction $^{132}$ of the fourth amendment in Boyd $v$. United States, ${ }^{133}$ the theme of an underlying right of privacy lias run througl the decisions and commentaries dealing with that amendment. ${ }^{134}$ However, at the outset of any discussion of such an underlying riglit, one is met by the language of the amendment itself: it forbids only "unreasonable searches and seizures."135 It is certainly arguable that some kinds of searches and seizures would be unreasonable per se. Analytically, there appear to be two different kinds of problems involved in the discussion of reasonableness in this context. First, the fourth amendment permits reasonable searches. This means, in the context of the inere evidence rule, a search of premises $^{136}$ supported either by a warrant issued on a showing of probable cause "and particularly describing the place to be searched, and the . . . things to be seized," or by a lawful arrest on the premises. ${ }^{137}$ In this sense of the word reasonable, the mdividual's right to be free from unwar-

sion in Thayer, $63 \mathrm{Cal}$. 2d at 642-43, 408 P.2d at 112-13, 47 Cal. Rptr. at 784-85, with Judge Hand's discussion in Kirschenblatt, 16 F.2d at 203-04.

131 In invalidating the seizure of a large quantity of books and papers which allegedly concerned the Communist Party of Texas, the United States Supreme Court recently held that the fourth amendment's requirement "that warrants must particularly describe the 'things to be seized' is to be accorded the most scrupulous exactitude when the 'things' are books, and the basis for their seizure is the ideas they contain. . . . No less a standard could be faithful to First Amendment Freedoms. . . . We need not decide in the present case whether the description of the things to be seized would have heen too generalized to pass constitutional muster, had the things been weapons, narcotics or 'cases of whiskey.' . . . The point is that it was not any contraband of that kind which was ordered to be seized, but literary material ...." Stanford v. Texas, supra note 130, at 485-86.

132 See note 37 supra and accompanying text.

133116 U.S. 616 (1886).

134 Id. at 630. Sec, e.g., Olmstead v. United States, 277 U.S. 438, 471 (1928) (Brandeis, J. dissenting); Gouled v. United States, 255 U.S. 298, 309 (1921); Warren and Brandeis, The Right to Privacy, 4 HARv. L. REv, 193 (1890).

135 U.S. Const. aniend. IV.

136 This discussion is limited to the searches of premises because the mere evidence rule has not been thought applicable to searches of the person. See note 96 supra.

137 United States v. Rabmowitz, 339 U.S. 56 (1950); Harris v. United States, 331 U.S. 145 (1947). 
ranted invasions of his physical privacy is balanced against the government's need to enforce its criminal laws.

But there is arguably a second meaning of reasonableness. Justice Bradley suggested in Boyd $d^{138}$ that the framers of the fourth amendment included in their concept of reasonableness the notions expressed in Entick. There Lord Camden invoked principles which are presently protected in our system by the first and fifth amendments. ${ }^{139}$ Justice Bradley argued on the basis of Entick that the fourth and fifth amendments run almost into one another. ${ }^{140}$ In fact, as Entick demonstrates, the protection of the values presently embodied in the first, fourth, and fifth aniendments were viewed as a single problem. ${ }^{141}$ The decision in Entick was a victory for the freedom of conscience rather than a vindication of common law property concepts. The mechanism used is now found in the fourth amendment, but the rights protected find expression in the first and, perhaps, the fifth amendments. When the three aniendments are read together, there is arguably an area of mental or personal privacy into which it is not possible for the government to enter in a reasonable manner. ${ }^{142}$ It is submitted that the seizure of private papers invokes this conjunction of values and results in the concern expressed by courts over the inclusion of a personal diary in the definition of an instrumentality. ${ }^{143}$ The mere evidence cases have not raised any first amendment issues. ${ }^{144}$ Whether they raise fifth amendment issues will be examined below; but pending that discussion, it is not inconsistent with our history and traditions to read the fourth amendment's requirentent of "reasonableness" as permitting the seizure of Mr. Gouled's or Dr. Thayer's papers.

\section{B. The Protection of the Right Against Self-Incrimination}

A second argument made in support of the mere evidence rule is that it protects the right against self-incrimination. ${ }^{145}$ Chief Justice Traynor

138116 U.S. at $626-27$.

13919 How. St. Tr. 1029 (1765), quoted in Boyd v. United States, 116 U.S. 616, 627-29 (1886); see Landynskt, Searce and Setzure and the Supreame Court 28-30 (1966).

140116 U.S. at 630.

${ }^{141}$ Stanford v. Texas, 379 U.S. 476, 484-85 (1965); see Kaplan, Search and Seizure: A No-Man's Land in the Criminal Law, 49 CArIF. L. REv. 474, 475-76 (1961).

142 See Griswold v. Connecticut, 381 U.S. 479, 484-85 (1965).

$143 \mathrm{Cf}$. authorities cited note 122 supra.

144 This is because first amendnient problems are generally dealt with in first amendment terms. In some cases the validity of a seizure may turn on a determination of whether the property seized is entitled to first amendment protection. This is not uncomnion in obscenity cases. See Marcus v. Search Warrant, 367 U.S. 717 (1961). In a rare case, first amendment rights may be protected by fourth amendment principles. See Stanford v. Texas, 379 U.S. 476 (1965) (a search warrant for political books was held invalid because the description of the itenis to be seized was not sufficiently particular).

145 Note, 54 GEo. L.J. 593, 624 (1966). 
argues that there are two reasons why the rule does not protect this right. ${ }^{146}$ First, the rule is not limited to self-incriminating writings. While this is certainly true ${ }^{147}$ the three Supreme Court cases excluding evidence on the basis of "mere evidence" theories ${ }^{148}$ involved writings, and it would not be illogical to restrict the rule to this class of evidence. Second, papers classed as instrumentalities are no less incriminating than those classed as mere evidence. This argument seems to be adequate, in itself, to deal with the standard form of the rule. However, it does not answer Dr. Thayer's contention that it is anomalous to permit the seizure of his records when he could not be required to produce them pursuant to a subpoena. ${ }^{149}$ Chief Justice Traynor answers this contention by pointing out that unlike seizure, production pursuant to a subpoena constitutes testimony supplied by an implied statement that the documents are genuine. This distinction corresponds to the rationale generally given for the inclusion of documentary evidence under the privilege against selfincrimination. That is, the privilege does not bar all incriminatory evidence obtained from an individual by compulsory process. Rather, the privilege bars the admission of sucl evidence only if it is testimonial in cliaracter. ${ }^{150}$ However, documentary evidence could be viewed as sufficiently "testimonial" in character to be excluded on that ground alone without recourse to the doctrine of implied testimony. It is submitted that the doctrine of implied testimony is a fiction which masks the more fundamental question of whether the value clioices embodied in the fifth amendment's privilege against self-incrimination are focused on the oral character of the evidence or on the fact that it is a product of the mind. In other words, the question is what characteristics delineate the concept of "testimonial" compulsion. The cases-lolding that the introduction of evidence produced by sucl activities as compelling a person to appear in a line-up, try on clothing, or give a sample of blood does not violate the privilege $^{151}$ - do not raise this issue. Apart from the fiction of implied testimony, it is not self-evident that the seizure of a document, immune from compulsory process under the fifth amendment, is more like the compulsory giving of a blood sample than it is the compulsory giving of oral testimony which is incriminatory. ${ }^{152}$ Therefore, despite all its doctrinal support, Chief Justice Traynor's argument is not persuasive.

14663 Cal. 2d at 638, 408 P.2d at 110, 47 Cal. Rptr. at 782.

147 E.g., Morrison v. United States, 262 F.2d 449 (D.C. Cir. 1958).

148 United States v. Lefkowitz, 285 U.S. 452 (1932); Gouled v. United States, 255 U.S.

298 (1921); Boyd v. United States, 116 U.S. 616 (1886).

149 See note 23 supra and accompanying text.

1508 WigMore $\S 2263$.

151 Schmerber v. California, 384 U.S. 757 (1966); People v. Trujillo, 32 Cal. 2d 105, 194 P.2d 681, cert. denied, 335 U.S. 887 (1948).

152 Boyd v. United States, 116 U.S. 616 (1886). 
The answer to this question is not to be found in the cases. The most recent pronouncement of the Supreme Court is contained in Schmerber $v$. California ${ }^{153}$ which involved the admissibility of the results of a blood sample establishing alcohol content. The sample was taken from the defendant by compulsion. The Court leld that the privilege against selfincrimination was not available as a basis for excluding the results of the blood test because there was not "even a shadow of testimonial compulsion ... or enforced communication."154 However, the Court indicates that it takes a broad view of testimonial compulsion. "It is clear that the protection of the privilege reaches an accused's communications, whatever forn they miglit take, and compulsion of responses which are also communications, for example, compliance with a subpoena to produce one's papers."155

But the question is whether the fifth amendment's privilege against self-incrimination can be of aid in the process of attempting to define the term "reasonable" in the fourth amendment. The answer to this question is largely determined by what rationale one accepts for the existence of the privilege. The issue dealt with here concerns the reasonableness of the seizure of certain kinds of documents rather than the reasonableness of the search. ${ }^{156}$ Unlike the first amendment, the fifth amendment is directly involved in striking the balance between the individual and the state in the enforcement of criminal law. Further, in the Court's view, the fifth amendment seems to be assuming a dominant position in defining the character of our system of administering criminal justice. The Court has stressed the central role of the privilege in protecting the adversary character of the system..$^{157}$ Given this concern with the fifth amendment, the Court might well find fifth amendment analogies persuasive in a close case.

Assuming that the Court night be persuaded to draw on the fifth amendment in determining whether there should be some limitation on the nature of the objects which may be seized beyond the requirement that they be the product of a reasonable search, the question remains whether the fifth amendment privilege against self-incrimination supports such a limitation. This, in turn, depends on wliy a person is privileged not to incriminate himself. One theory advanced in support of the privilege explains that it is but a recognition of the basic mstinct of self-preservation. ${ }^{158}$ A nian faced with the choice of speaking the words which might

153384 U.S. 757, 760-65 (1966).

$154 I d$, at 765 .

155 Id. at 763-64, citing Boyd v. United States, 116 U.S. 616 (1886).

156 See text accompanying notes 137-142 supra.

157 See Miranda v. Arizona, 384 U.S. 436, 442-44, 457-60 (1966); Malloy v. Hogan, 378

U.S. 1, 7-8 (1963).

158 MCCORMICK, EvIDENCE 289 (1954). 
subject him to punishment cannot be forced to speak the truth unless the penalty for refusing to speak is as certain and as severe as the one threatened. A related theory finds it uncivilized to put a man to the choice of lying under oath or convicting himself. ${ }^{150}$ Neither of these theories would support an extension of the privilege by reading it into the requirement of reasonableness in the fourth amendment. Since both of these theories focus on action required of the individual, and since he is not required to act when papers are seized from hin, they support the distinction drawn by Chief Justice Traynor between production pursuant to a subpoena and a seizure. It is submitted that neither of these theories reflects the current attitude of the Court. ${ }^{160}$

McNaughton suggests four policies ${ }^{161}$ underlying the privilege against self-incrimination. These can be applied to the problem at hand. The first is that the privilege aids in frustrating the enforcement of bad laws. ${ }^{162}$ The listory of the privilege is compatible with the argument that the rationale for the privilege was the desire to provide a check on governmental power in order to avoid its exercise in an arbitrary fashion. ${ }^{183}$ Any extension of the privilege would certainly be a check on governmental power. However, there are considerations which cut against the extension of the privilege under this theory. First, inasmuch as any linit on governmental power, no matter how arbitrary, accomplishes the same end, ${ }^{164}$ this argunent simply raises the further question of the desirability of the particular clieck proposed. Second, the better course is to proceed directly against bad laws. Indirect rules also hamper the enforcement of laws having substantial community acceptance. In the area of exclusionary rules, there are strong pressures to limit the grounds on which evidence that is otherwise highly probative can be excluded. ${ }^{165}$ The result is often

159 Ibid.

100 See Schmerber v. California, 384 U.S. 757 (1966); Miranda v. Arizona, 384 U.S. 436 (1966); Murphy v. Waterfront Comm'n, 378 U.S. 52 (1964); Malloy v. Hogan, 378 U.S. 1 (1964).

161 McNaughton-the editor of the 1961 edition of WIGMORE-discusses twelve such policies, but contends that only the four mentioned in the text adequately justify the privilege. 8 WIGriore $\$ 2251$, at $310-313$. He characterizes the three originally suggested by WigInore-that the privilege protects the innocent defendant from being convicted by a bad perfornance, avoids burdening the court with false testimony, and encourages third party witnesses to testify-as "makeweights." 8 WIGMORE $\$ 2251$, at 311. These three rationales would not support an extension of the privilege against self-incrimination to the production under compulsory process. However, given Wigmore's well-known general hostility to exclusionary rules, it is not surprising that none of the justifications he advances would support any further extension of the privilege.

1628 WIGMORE $\$ 2251$, at 313 .

163 See authorities cited in note 141 supra.

164 Kaplan, supra note 141, at 478-79.

165 Id. at 503; Manwaring, supra note 111, at 348-49. 
a rule, undermined by complex exceptions, which in time offers no protection, as the history of the mere evidence rule illustrates.

The second rationale McNaughton suggests for the privilege is its prevention of the use of the criminal law for illegitimate purposes. ${ }^{166}$ There is hittle doubt that such abuse does occur even if its extent is hard to measure. ${ }^{107}$ As McNaughton points out, this rationale is largely a variant of the first. The third rationale is that the privilege prevents the use of torture and similar abuse. ${ }^{168}$ While this rationale may well provide substantial support for the privilege, ${ }^{169}$ it does not support an extension since permitting the seizure of papers caunot be reasonably expected to lead to such tactics.

The fourth rationale considers the maintenance of a "fair" stateindividual balance as the justification for the privilege. ${ }^{\mathbf{1 7 0}}$ The recent series of cases $^{171}$ extending the protection of the fifth and sixth amendments to an earlier stage of the proceedings than had been previously thought necessary seems to be founded on something approaching this rationale. One plausible explanation for these cases is that the Court is attempting to protect the individual from investigatory procedures which make the adversary trial a mere formahty. ${ }^{172}$ In doing so, the Court is at least in part protecting the individual-state balance. Given this view, the Court might look with favor on an argument which suggests that to permit the seizure of evidence immune from compulsory process under the fifth amendment is to upset this balance.

\section{CONCLUSTON}

People v. Thayer has made a substantial step toward the demise of the mere evidence rule. The question remains whether this development will result in removing all restrictions on the government's power to seize property for use as evidence where the preceding search is otherwise lawful. The fourth amendment alone does not provide a basis for such limitation. However, given the United States Supreme Court's present concep-

1608 WIGMORE § 2251, at 314.

167 See e.g., Monroe v. Pape, 365 U.S. 167 (1961); U.S. Comar's on CIVII RIgHTS, Law Emporcemient, A Report on Equal Protection IN the South (1965); Cal. Advisory

Conar. to U.S. Comar's on CIVIL Rights, Police-Mnority Group Relations (1963). 1088 WIGMORE \& 2251, at 315.

169 See Miranda v. Arizona, 384 U.S. 436, 446-57 (1966); Brown v. Mississippi, 297 U.S. 278 (1936).

1708 WIGMORE $\S 2251$, at 317.

171 Miranda v. Arizona, 384 U.S. 436 (1966); Escobedo v. Hlinois, 378 U.S. 478 (1964); Murphy v. Waterfront Comm'n, 378 U.S. 52 (1964); Malloy v. Hogan, 378 U.S. 1 (1964); Massiah v. United States, -377 U.S. 201 (1964); People v. Dorado, 62 Cal. 2d 338, 398 P.2d 361, 42 Cal. Rptr. 169, cert. denied, 381 U.S. 937 (1965).

172 Developments in the Law-Confessions, 79 HARV. L. REv. 935, 973-74 (1966). 
tion of the fifth amendment's privilege against self-incrimination, there is considerable force to the argument that seizure should not be permitted where production under compulsory process would be barred by the fifth amendment. But, however the constitutional balance is read, the rejection of the mere evidence rule is important because it lays bare the real issues which should be faced in determining any ultimate limitations on the power of seizure.

William T. Rintala 